\title{
Análisis del tamaño de partículas en areniscas de las Catedrales de Salamanca. Independencia entre granulometría y deterioro
}

\author{
Analysis of the size of sandstone particles from the \\ Cathedrals of Salamanca. Independence between \\ granulometry and deterioration
}

\author{
M.T. MARTIN PATINO \\ CSIC y Departamento de Química Agrícola y Geología \\ Universidad Autónoma. Canto Blanco. Madrid \\ F. MADRUGA \\ Euroconsult. Salamanca \\ J. SAAVEDRA \\ IRA/CSIC. Salamanca
}

ESPAÑA

Fecha de recepción: 09-XII-1993

\section{$R E S U M E N$}

Se analizan granulométricamente 11 muestras de arenisca de las Catedrales de Salamanca. El objetivo del estudio es establecer si existe relación directa entre el tamaño de las partículas de tales piedras y el deterioro superficial de alguno de los sillares de las fachadas. Esto se lleva a cabo con la ayuda de la espectrometría de difracción por rayos láser.

Los resultados muestran que no hay conexión entre la finura textural de las piedras estudiadas y el grado de deterioro superficial que éstas presentan.

\section{$S U M M A R Y$}

11 sandstone samples from the cathedrals of Salamanca were analysed granulometrically. The study was to establish whether there is a direct connection between the particle size of such stone and the surface deterioration of some of the ashlars in the façades. This was carried out with the help of difraction spectrometry by laser beams.

The results show that there is no connection between the nature of the stone texture and their degree of surface deterioration.

\section{INTRODUCCIÓN}

Este estudio forma parte de los que venimos realizando sobre la arenisca de Villamayor como material de construcción en general, y más concretamente la arenisca en el monumento de las Catedrales de Salamanca.

\section{INTRODUCTION}

This is another of the studies on Villamayor sandstone as a general building material. In this case sandstone from the cathedrals of Salamanca was used. 
El objetivo principal era encontrar si hay una relación directa o no entre el tamaño de las partículas de las piedras y el deterioro superficial que éstas presentan en algunos bloques. La alteración selectiva, es decir, bloques de piedra con deterioro superficial contiguos a otros sin ningún signo de deterioro en el mismo paramento de un edificio, puede ser observada no sólo en las Catedrales, sino en el conjunto de los monumentos de la ciudad.

Para este fin, el tamaño de las partículas, o granos minerales, componentes de las muestras de piedra tomadas de los edificios de ambas

Catedrales, se analizan en detalle. Estas mismas muestras fueron caracterizadas con anterioridad, bajo los aspectos físico-químico y físico-mecánico (1).

\section{MATERIALES Y MÉTODO}

El muestreo se realizó en las dos Catedrales, seleccionando zonas en las que la situación, orientación, y las condiciones ambientales son diferentes. Dos bloques de piedra contíguos o cercanos unos de otros se eligieron de cada una de estas zonas. La superficie de uno de ellos está visiblemente deteriorada, mientras que la del otro está sin deterioro, pero ambos sometidos a los mismos factores de alteración externos.

De cada bloque se extrajeron dos testigos de 10 a $20 \mathrm{~cm}$ de longitud y $10 \mathrm{~cm}$ de diámetro, cortando de cada uno de los extremos, parte interna (I) y parte externa (E), rodajas aproximadamente de $2 \mathrm{~cm}$ de espesor.

Como ya hemos indicado en trabajos anteriores, este muestreo se realizó con el arquitecto que dirigía la restauración de las catedrales y el grupo de investigadores que realizaba el proyecto de investigación CE87-0014-C05-01.

La enumeración de las muestras que se estudian y las zonas a las que corresponden son las siguientes:

- Zona baja e interior de entrada a la Torre Mocha, bloque deteriorado (101) y bloque no deteriorado (102).

- Zona baja e interior, escalera de la Torre Mocha, bloque deteriorado (201) y bloque no deteriorado (202).

- Zona alta, nivel $1^{\circ}$, fachada exterior orientada al sur, bloque deteriorado (1101) y bloque no deteriorado (1102).
The main objective was to find whether there is a direct relationship or not between the particle size of the stone and the surface deterioration found in some blocks. Selective alterations, ie, stone blocks with surface deterioration next to others without any sign of decay in the same building area, can be observed not only in the cathedrals, but in all the monumental buildings of the city.

To this end, the particle size, or mineral grains, in the stone samples taken from the buildings of both cathedrals were analysed in detail. Before that the physico-chemical and physico-mechanical characteristics (1) of these samples were established.

\section{MATERIALS AND METHOD}

The samples from both cathedrals were chosen from areas with differing situations, orientations and environmental conditions. Two blocks of stone close or next to each other were chosen in each of these areas. The surface of one of them would be deteriorated visibly, while the other would be unaffected, but both would be subject to the same external alteration factors.

Two samples, 10 to $20 \mathrm{~cm}$ long and $10 \mathrm{~cm}$ in diameter, were extracted from each block and discs with a thickness of about $2 \mathrm{~cm}$ were cut from both ends, the internal (I) and external (E) part.

As was pointed out in previous studies, the samples were taken by the architect in charge of restoring both cathedrals and the group of researchers of the research programme CE87-0014-C05-01.

The numbered samples and the areas to which they belong are the following:

- Lower and interior area of the entrance to the Torre Mocha: deteriorated block (101), unaffected block (102);

- Lower and interior are of the Torre Mocha stairs: deteriorated block (201), unaffected block (202);

- Upper area, lst level, on the southern façade: deteriorated block (1101), unaffected block (1102); 
- En el mismo nivel que la anterior, fachada exterior orientada al norte, bloque deteriorado (1201) y bloque no deteriorado (1202).

\section{- Zona alta, nivel $2^{\circ}$, fachada exterior orientada al oeste, bloque deteriorado (2101) y bloque no deteriorado (2102).}

\section{- Placa superficial de bloque deteriorado en fachada} exterior.

En cada uno de los testigos se ha estudiado la parte interna y la parte externa o superficial.

Con el fin de comparar las semejanzas o diferencias de estas piedras con la arenisca extraída en la actualidad de la cantera de Villamayor, tres muestras de la misma estudiadas en trabajos anteriores (2) y (3) se incluyen en esta parte. Cada una de estas muestras corresponde a un tipo de calidad diferente, F, M y G. Ninguna de las areniscas estudiadas en los trabajos citados contienen carbonatos.

Las muestras se desagregaron sin fracturar los granos, y cantidades iguales en peso de cada una de ellas se agitaron en agua con dispersante.

Para el análisis granulométrico ha sido usada la técnica de espectometría de difracción por rayos láser, equipo tipo Simpatec Helos $12 \mathrm{~K} \mathrm{~A}$, acoplado a un sistema de recogida y tratamiento de datos, e impresora. La técnica está basada en la difracción de la luz producida cuando se hace pasar un rayo láser a través de una muestra dispersa. La descripción del equipo y las ventajas de su utilización en cuanto a rapidez, precisión y reproducibilidad han sido relatadas por otros autores (4). Las distancias focales usadas fueron 500 y 100 milímetros, que corresponden a rangos de medida desde 4,5 a $850 \mu \mathrm{m}$ y desde 0,75 a $175 \mu \mathrm{m}$ respectivamente. En el tamaño de $850 \mu \mathrm{m}$ quedan incluidos todos los tamaños de granos presentes en las muestras que se estudian. El rango segundo fue usado para apreciar mejor la distribución de los tamaños más finos. El sistema de alimentación utilizado ha sido en fase húmeda.

El analizador dispone de un detector multicelular con 31 canales de medición, es decir, hace medidas en 31 tamaños diferentes. Los listados de datos que proporciona el equipo son los siguientes: tamaño correspondiente a cada una de las medidas que va a realizar; porcentaje del volumen de partículas con tamaños inferiores al que corresponde dicha medida; idem con tamaños superiores; tamaño medio entre dos medidas; densidad de distribución (en expresión logarítmica) de partículas para cada tamaño medido; y
- At the same level as the above, on the northern façade: deteriorated block (1201), unaffected block (1202);

- Upper area, 2nd level, on the western façade: deteriorated block (2101), unaffected block (2102);

- Surface layer of a deteriorated block on the façade.

The internal and external or surface parts were studied in each of the samples.

For reasons of comparing the similarities or differences of these stones with the sandstone extracte today from Villamayor quarry, three samples studied in previous papers (2), (3) are included from that site. Each of them belong to a type of different quality, $F, M$ and $G$. None of the sandstones studied in the papers mentioned before contain carbonates.

The samples were broken up without fracturing the grain, and amounts of the same weight from each were shaken in water with a dispersing agent.

For the granulometric analysis difraction spectrometry by laser beams was used, an equipment of the Simpatec Helos $12 \mathrm{~K}$ A type, connected to a system for data collection and treatment and to a printer. The equipment and its advantages as regards speed, precision and reproducibility have been described by other authors (4). The focal distances used were 500 and 1000 millimetres, which correspond to measuring ranges of between 4.5 and $850 \mu \mathrm{m}$ and of between 0.75 and 175 $\mu m$, respectively. Size $850 \mu \mathrm{m}$ includes all the grain sizes found in the samples. The second range was used for a better appreciation of the distribution of the smallest sizes. The feeder system used was that in the humid phase.

The analyser has a multicell detector with 31 measuring channels, ie, it measures in 31 different sizes. The data lists of the equipment are the following: upper band limit; percentage under cumulative; percentage over cumulative; average for band; density logarithm; volume percentage of each particle size. Other data provided by the analyser for each sample are: the size below which $10 \%$ of the total particle volume accumulates, the same for $50 \%$ (called median), the same for $90 \%$, as well as the percentage of particles of 
porcentaje del volumen de partículas para cada tamaño medido. Otros datos que reporta el analizador para cada muestra son: el tamaño por debajo del cual se acumula el $10 \%$ del volumen total de partículas, idem para el $50 \%$ (llamado mediana), idem para el $90 \%$, así como el porcentaje de partículas de tamaño inferior a $32 \mu \mathrm{m}$, idem inferior a $45 \mu \mathrm{m}$, idem inferior a $90 \mu \mathrm{m}$, además de la superficie específica de la muestra en $\mathrm{m}^{2} / \mathrm{cm}^{3}$ y en $\mathrm{cm}^{2} / \mathrm{g}$.

\section{RESULTADOS E INTERPRETACIÓN}

Por razones de espacio no todos los listados de datos que el equipo proporciona son publicados. Los valores más representativos de éstos se exponen en dos tablas y 8 figuras gráficas.

Las curvas acumulativas de las figuras 1 y 2 corresponden a la parte interna de las muestras. Cada punto de una curva representa el porcentaje, en volumen, de partículas con tamaño inferior al que corresponde al punto en cuestión. Las formas que presentan estas curvas expresan semejanzas en la distribución granulométrica de las muestras (101) (1201) y (1202) por una parte, y del resto de las muestras por otra. En las del grupo primero el $80 \%$, aproximadamente, de partículas corresponde a tamaños inferiores a $100 \mu \mathrm{m}$, y de éstas el $10 \%$ están por debajo de $4,5 \mu \mathrm{m}$, siendo el tamaño mayor de a rena de $365 \mu \mathrm{m}$, son areniscas de granulometría fina. En las muestras del grupo segundo el $50 \%$ de las partículas tienen tamaños inferiores a $300 \mu \mathrm{m}$, y los inferiores a $100 \mu \mathrm{m}$ superan el $30 \%$; el tamaño mayor de arena es del orden de $675 \mu \mathrm{m}$.

Las figuras 3 y 4 muestran las curvas acumulativas que resultan de usar el rango de medición de 0,75 a $175 \mu \mathrm{m}$ en el analizador. Ellas dan una imagen más precisa de la distribución de los tamaños finos, correponden a las muestras de las Catedrales -las mismas que en las figuras anteriores- más otras tres procedentes de la cantera de Villamayor, F, M y G.

Estas curvas presentan, con más precisión que las anteriores, dos segmentos o tramos claramente diferenciados, los cuales relacionan la distribución granulométrica de la arenisca al transporte que tuvieron estos materiales hasta su deposición y formación del sedimento. El punto de inflexión próximo a $100 \mu \mathrm{m}$ es el punto en el que los hidrogeólogos fluviales notifican cambios marcados en la distribución del tamaño del material, principalmente del que ha sido transportado por suspensión (5). El segmento primero de estas curvas, en forma de "S" bien definida, corresponde al material más fino, $<100 \mu \mathrm{m}$, e indica un transporte por deposición bien clasificado. a size below $32 \mu \mathrm{m}$, below $45 \mu \mathrm{m}$, below $90 \mu \mathrm{m}$, in addition to the specific surface of the sample in $\mathrm{m} 2 / \mathrm{cm} 3$ and in $\mathrm{cm} 2 / \mathrm{gr}$.

\section{RESULTS AND INTERPRETATION}

For reasons of space not all the data lists produced by the equipment are published. Their most representative values are given in Tables and Figures.

The accumulative curves of Figures 1 and 2 belong to the internal part of each sample. Every point of a curve represents the volume percentage of particles with a size below that of the point in question. The forms of these curves show similaritiees in the granulometric distribution of samples (101) (1201) and (1202) on the one hand, as they do on the other hand for the rest. In those of the first group about $80 \%$ of the particles belong to sizes under $100 \mu \mathrm{m}$, and of those $10 \%$ under $4.5 \mu \mathrm{m}$ are sandstones of fine granulometry, with the largest sand size being $365 \mu \mathrm{m}$. In the samples of the second group 50\% of the particles have sizes under $300 \mu \mathrm{m}$, and those below $100 \mu \mathrm{m}$ are higher than $30 \%$ with the largest sand size being around $675 \mathrm{\mu m}$.

Figures 3 and 4 show the accumulative curves after using the measuring range of between 0.75 and $175 \mu \mathrm{m}$ in the analyser. They give a more precise picture of the distribution of the fine sizes and belong to the samples from the cathedrals - the same as in the previous figures - as well as to another three samples from the Villamayor quarry, ie, $F, M$ and $G$.

With more precision than the previous curves, they show two clearly distinguishable segments or sections, which relate the size distribution of the sandstone grains to the movement of the materials to where the sediment was deposited and from where the stone was extracted. The inflection point near $100 \mu \mathrm{m}$ is the point where fluvial hydrogeologists point to marked changes in the size distribution of the material, mainly of that transported by suspension (5). The first segment of these curves is in the form of a well-defined " $S$ " and corresponds to the finest material, $<100 \mu \mathrm{m}$, and indicates a transport by well-classified deposits. 

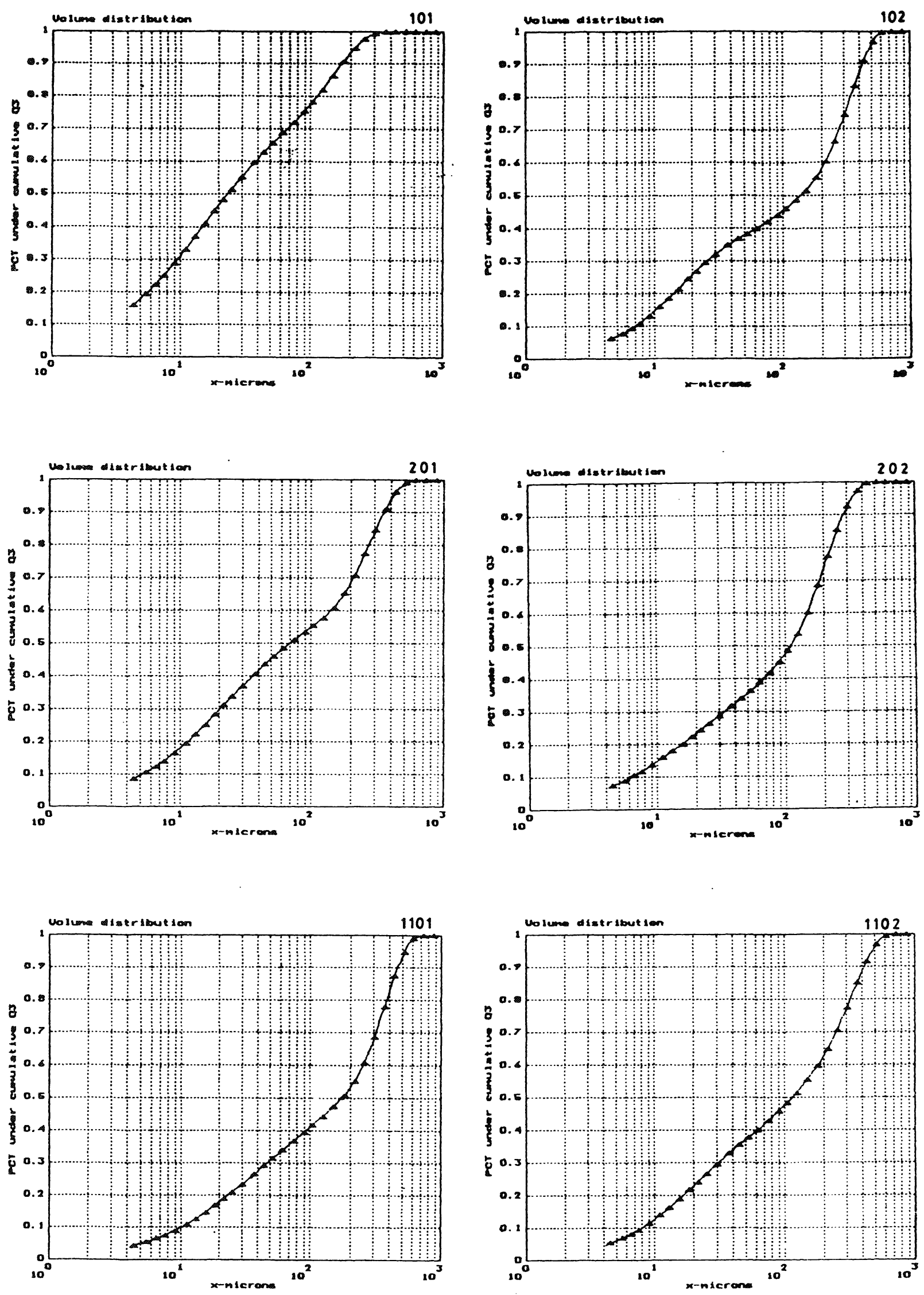

Fig. 1 - Curvas acumulativas, rango de medida en el analizador de 4.5 a $850 \mathrm{~m}$.

Fig. I-Accumulative curves after using measuring range of between 4.5 to $850 \mu \mathrm{m}$ in the analyser. 

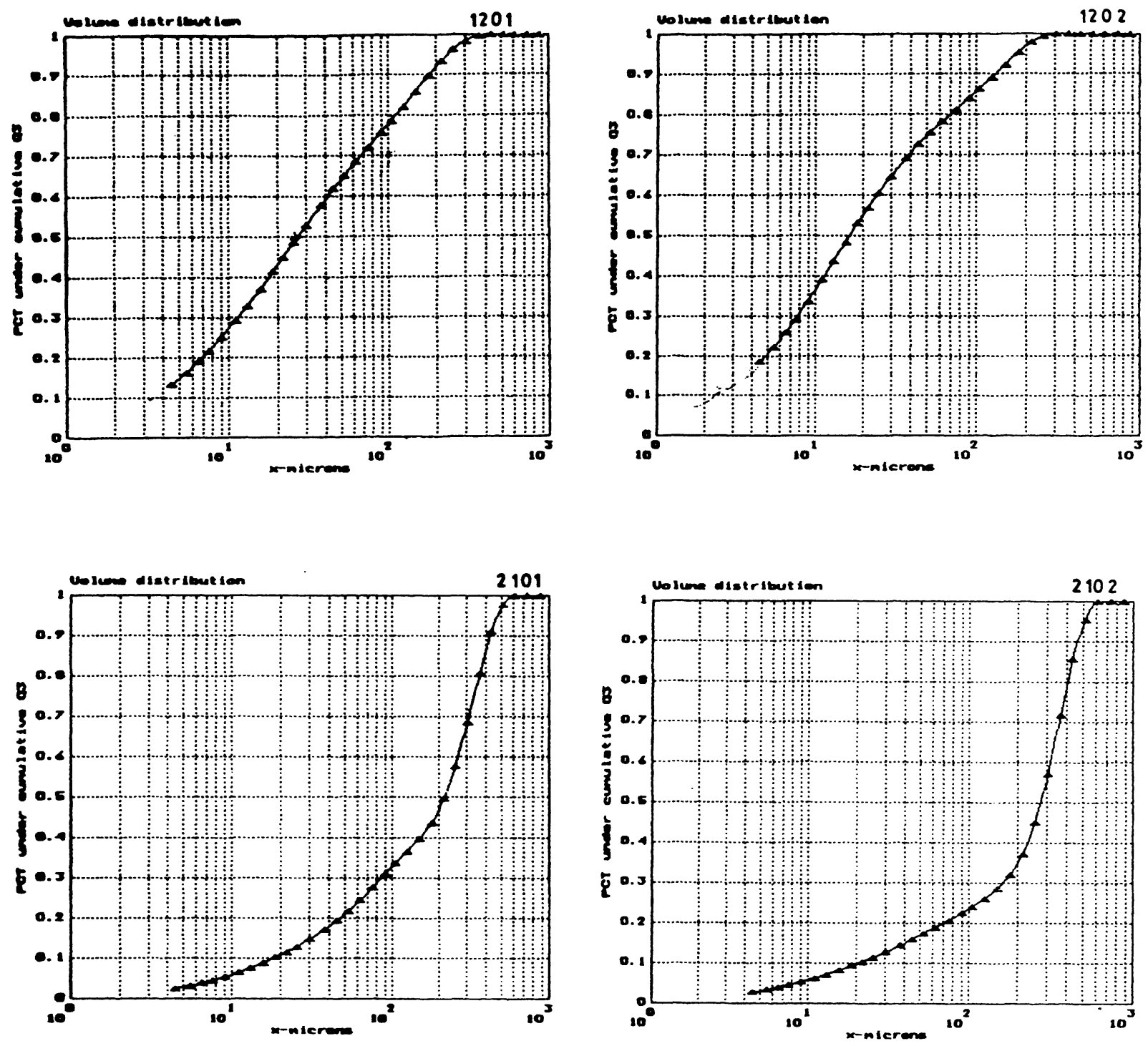

Fig. 2 - Curvas acumulativas, rango de medida en el analizador de 4.5 a $850 \mathrm{~m}$.

Fig. 2 - Accumulative curves after using measuring range of between 4.5 to $850 \mathrm{~m}$ in the analyser.

Esto coincide de forma igual en todas las muestras, permitiendo deducir que en la clasificación de las areniscas va a jugar un papel muy importante el porcentaje de partículas con tamaño inferior a $100 \mu \mathrm{m}$. El segmento segundo es recto y ascendente; corresponde al material de tamaño superior a $100 \mu \mathrm{m}$ transportado posiblemente por saltación; la proporción de este tramo aumenta en las muestras de cantera del tipo $\mathrm{M}$, y más aún en las de tipo $\mathrm{G}$, respecto a las otras del tipo $\mathrm{F}$ y del monumento.

Interpretamos la forma que presentan las curvas y el hecho significativo de sus semejanzas o diferencias, teniendo siempre en cuenta que las muestras proceden de un monumento, sin pretender sacar deducciones acerca de la estructura o dinámica del sedimento cantera.
This is the same for all the samples and allows the conclusion that the particle percentage with a size of less than $100 \mu \mathrm{m}$ will play a very important role in the classification of sandstone. The second segment is straight and ascending, belongs to material with a size of over $100 \mu \mathrm{m}$ possibly transported by skipping, and increases its proportion in the samples from the quarry of the $M$ type, even more so in those of $G$ type.

In this study the form of the curves and their significant similarities or differences are interpreted always taking into account that the samples were taken from monument without the intention of drawing conclusiones regarding the structure or dynamics of the sediment from which they come. 

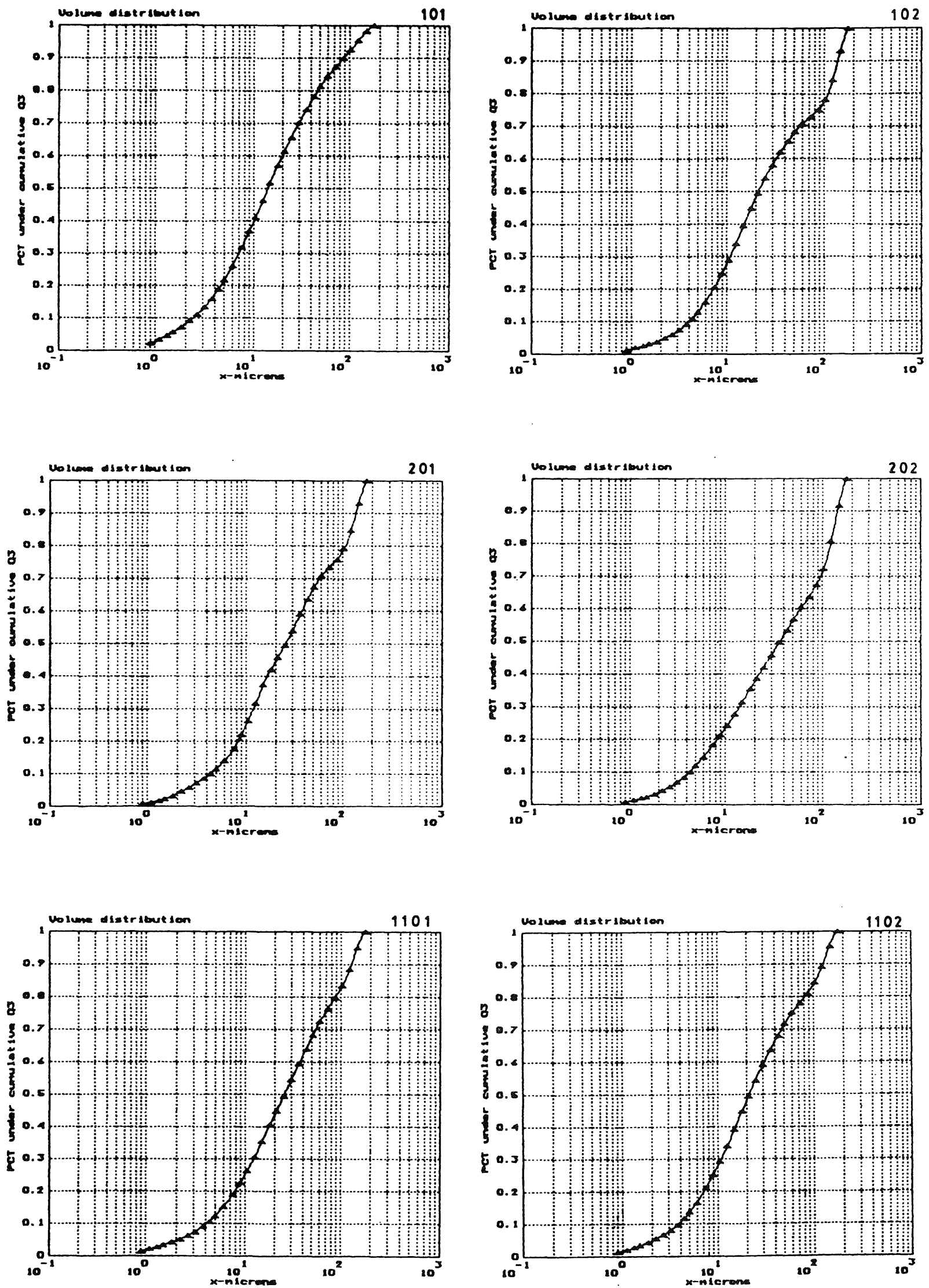

Fig. 3 - Curvas acumulativas, rango de medida en el analizador de 0.75 a $175 \mathrm{~m}$.

Fig. 3 - Accumulative curves after using measuring range of between 0.75 to $175 \mu \mathrm{m}$ in the analyser. 

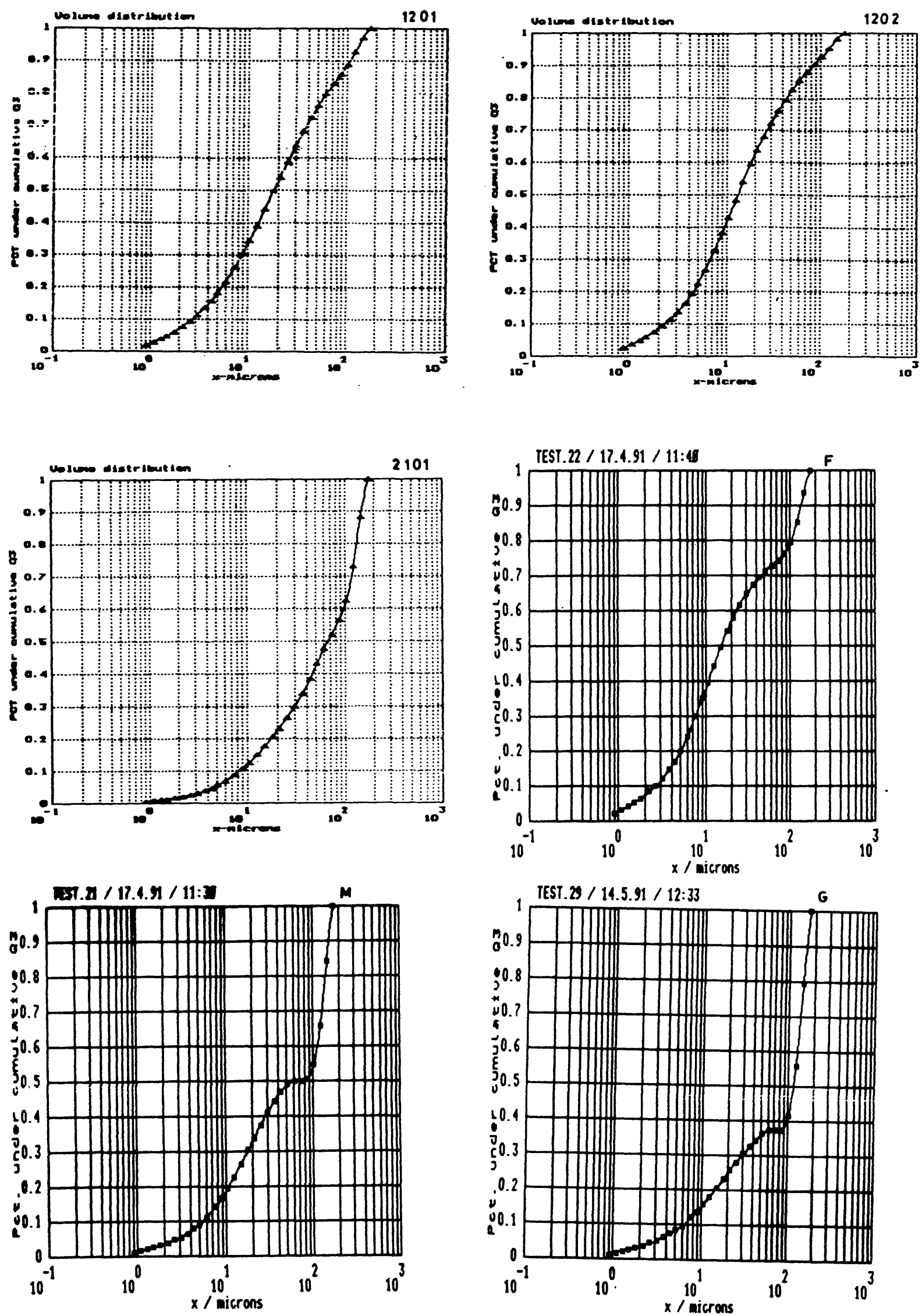

Fig. 4 - Curvas acumulativas, rango de medida en el analizador de 0.75 a $175 \mathrm{~m}$.

Fig. 4 - Accumulative curves after using measuring range of between 0.75 to $175 \mathrm{~m}$ in the analyser. 

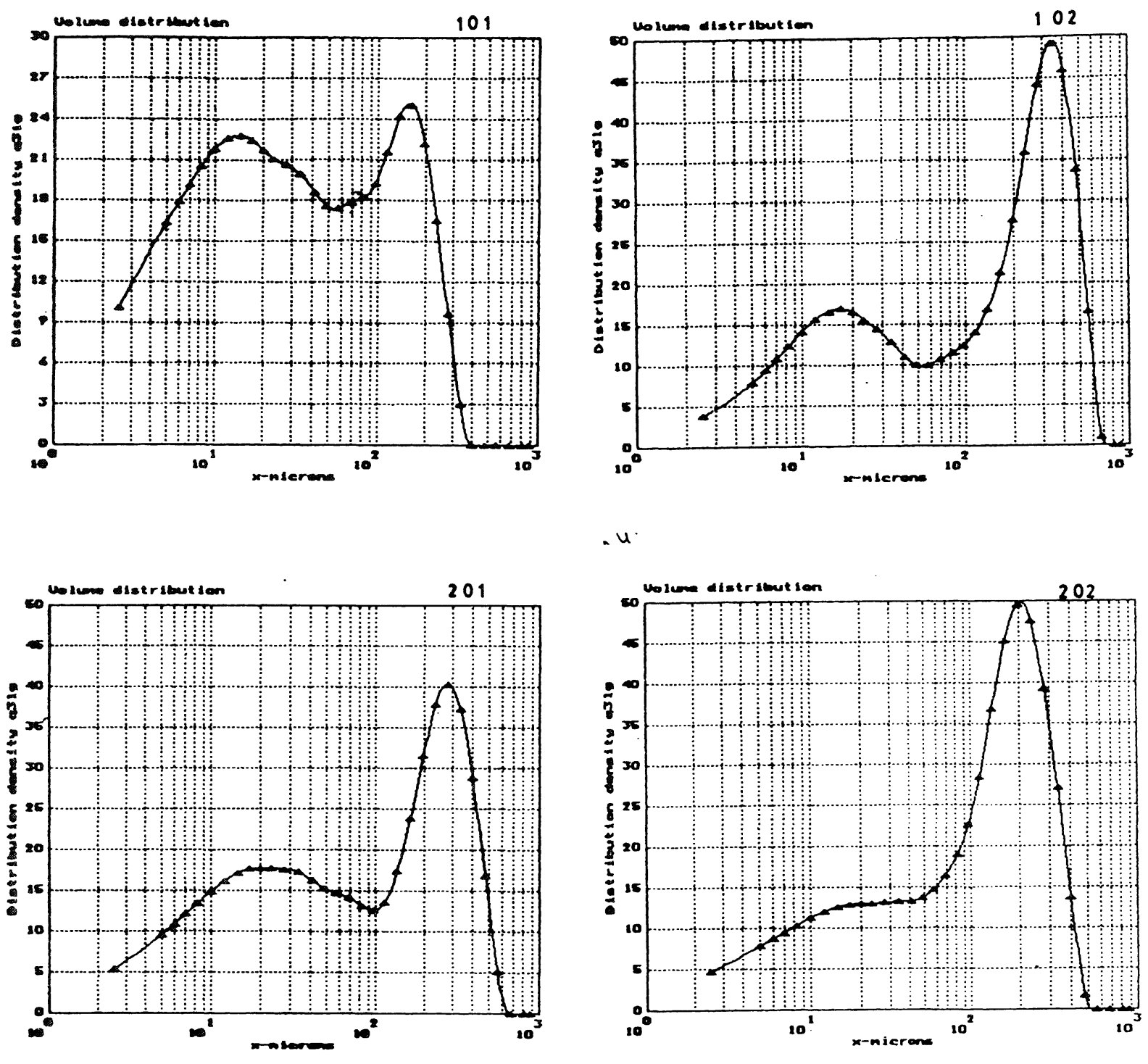

.4
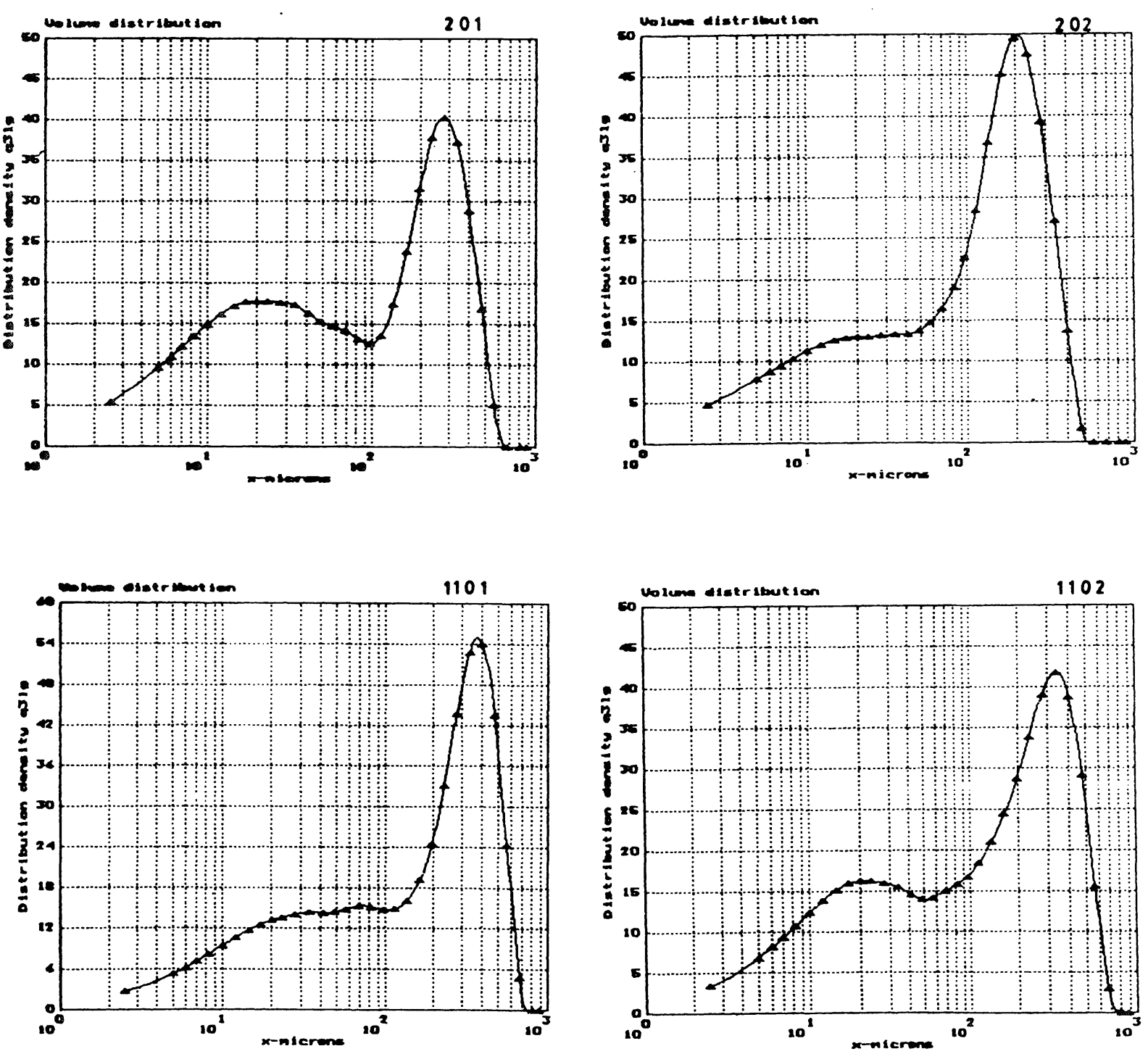

Fig. 5 - Curvas de densidad de distribución por tamaños.

Fig. 5 -Distribution density curves by sizes. 

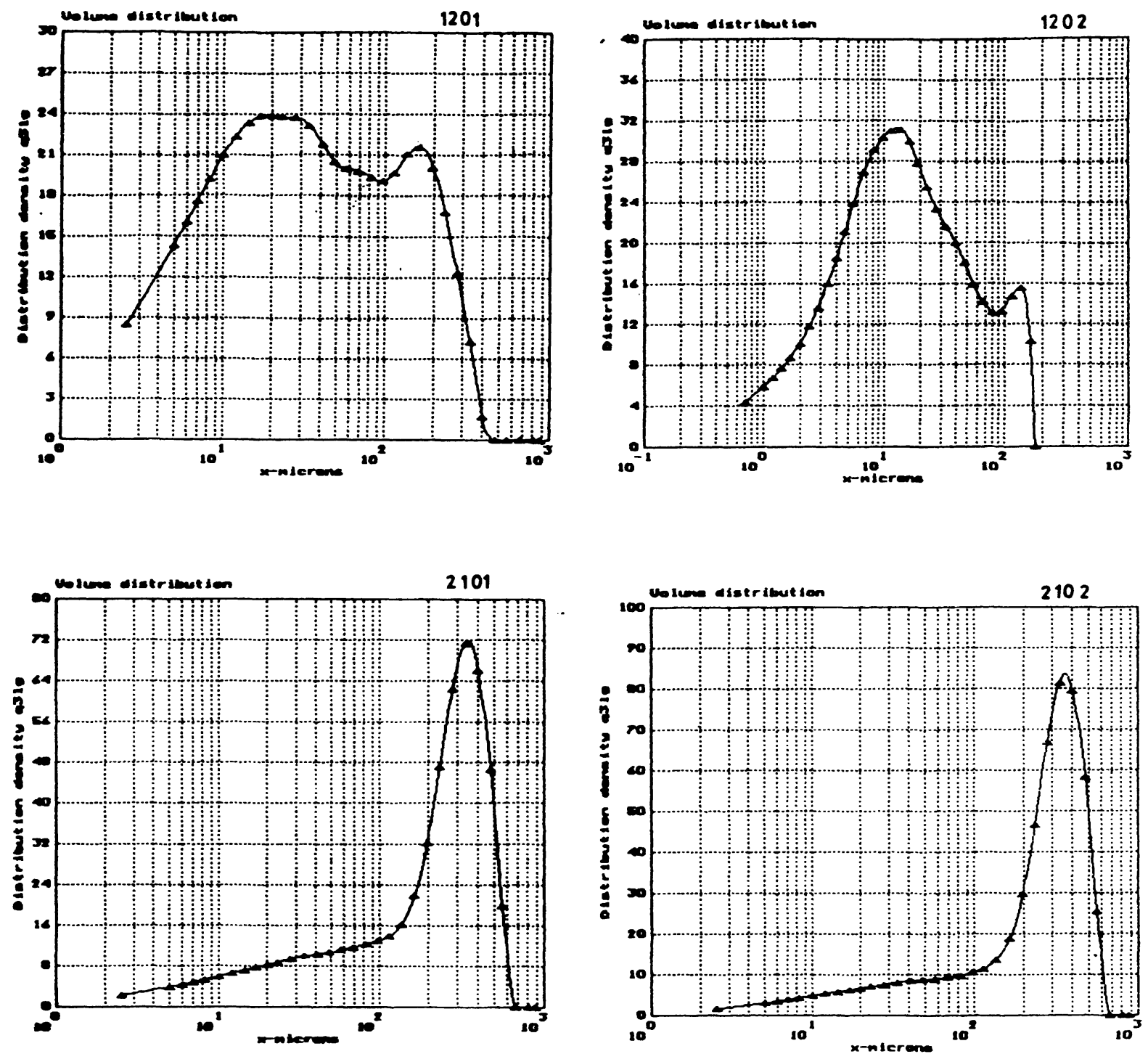

Fig. 6 - Curvas de densidad de distribución por tamaños.

Fig. 6 - Distribution density curves by sizes.

La repetición de forma en las curvas de unas muestras a otras es notoria, y supone la semejanza que, en cuanto a constitución física, tienen entre sí las piedras de donde proceden las muestras de las Catedrales, y de éstas con la piedra extraída en la actualidad de la cantera de Villamayor. Semejanza más acusada con las del tipo F.

Según el trabajo ya referido (3), las características tecnológicas de las areniscas del tipo $\mathrm{G}$ no reunen las condiciones adecuadas para su uso como material de construcción, y las de tipo $\mathrm{M}$ depende de la utilización para la que son requeridas.
The consistency of the form of the curves between the samples is obvious. This points to the similarity between them as regards the physical composition of the stone from where the samples of the Cathedrals come and of that stone compared with the stone extracted today from the Villamayor quarry. the similarity is more pronounced between the former and that from quarry corresponding to the $F$ type, the difference being greater in comparison with those of the $M$ and $G$ type, because the latter have lower percentages of fine particles.

According to the study mentioned earlier (3), the technological characteristics of type $G$ sandstone are not adequate for use as construction material, and those of type $M$ depend on the use to which they will be put. 
Las curvas de densidad de distribución de partículas, en expresión logarítmica por tamaños están representadas en las figuras 5 y 6 . Presentan dos tramos de forma gausiana muy bien definidos; el primero comprende los tamaños inferiores a $100 \mu \mathrm{m}$ y densidad máxima de partículas en el rango de 10 a $20 \mu \mathrm{m}$, en todas las muestras excepto la (2101). En el tramo segundo de tamaños superiores a $100 \mu \mathrm{m}$, el máximo de densidad varía de unas muestras a otras. Así en las muestras (101) (1201) y (1202) el tamaño de partículas más frecuente es de 100 a $200 \mu \mathrm{m}$; estas muestras ya se incluían en el mismo grupo por la semejanza en las curvas acumulativas. En las muestras restantes la frecuencia mayor está entre los tamaños de 300 y 400 $\mu \mathrm{m}$. La semejanza de todas las muestras respecto a la distribución de tamaños de grano más fino es confirmada, así como las diferencias en los tamaños arena.

En orden a relacionar más fácilmente las muestras deterioradas con las no deterioradas situadas en la misma zona del monumento, se representan en la figura 7 las curvas de las figuras anteriores acumulando en una gráfica las que corresponden a cada pareja de bloques. Las formas de las curvas de esta figura son semejantes entre parejas, con excepción de las de la zona baja (101) y (102) que, como se ha visto, son diferentes unas de otras; la primera es granulométricamente similar a las (1201) y (1202) y la segunda al resto de las muestras. Cuando comparamos cada pareja, se aprecia una ligera diferencia en los valores máximos. En las muestras que proceden de los niveles altos y exteriores del monumento, la deteriorada de cada pareja tiene menos partículas finas que la no deteriorada, con el correspondiente aumento del máximo de los tamaños gruesos. En las muestras de la zona baja e interior de la Torre, por el contrario, la densidad de las partículas finas es mayor en las deterioradas que en las no deterioradas. Esto es atribuido a la forma y causa del deterioro, diferente al de las situadas en las zonas altas y exteriores. En esta parte baja del edificio existe un grado de humedad muy alto, consecuencia de la absorción por capilaridad del agua subterránea, combinada con escasa ventilación que, edemás de producir desagregación de partículas, arrastra sales a través de los muros. Estas sales cristalizan y alteran la granulometría propia de la piedra (1).

La figura 8 muestra tres gráficas conteniendo las curvas de la parte interna (I) y externa (E) de un mismo bloque de piedra. Cada una de estas gráficas corresponde a bloques de zonas diferentes del monumento (de la parte baja y de los niveles $1^{\circ}$ y $2^{\circ}$ ), con el mismo efecto que ya
The logarithmic density curves by sizes are given in Figures 5 and 6. They have two well-defined Gauss-like sections, the first with sizes of up to around $100 \mu \mathrm{m}$ and maximum particle size density in the range of 10 to 20 $\mu m$ in all the samples except (2101). In the second section of sizes above $100 \mu \mathrm{m}$ maximum density varies from one sample to the next. Thus, in samples (101) (1201) and (1202), which were already included in the same group because of the similarity of their accumulative curves, the most frequent particle size is between 100 and $200 \mu \mathrm{m}$. In the remaining samples the most frequent size lies between 300 and $400 \mu \mathrm{m}$. The similarity of all the samples as regards the distribution of the finest grain sizes is confirmed as are the differences in the sand size.

In order to relate the deteriorated samples more easily with the unaffected ones in the same area of the building, Figure 7 shows the curves of the previous figures in one graph where those belonging to each pair of blocks are put together. As regards the pairs, the forms of the curves of this figure are similar, with the exception of those in the lower area (101) and (102), which, as can be seen, are different from each other, the former being granulometrically similar to (1201) and (1202) and the latter to the remaining samples. When comparing each pair, a slight difference is found in the values as regards the maxima, which represent the greatest particle density in that size. In the samples from the upper and exterior levels of the building, the deteriorated block of each pair has a lower density of sizes below $100 \mu \mathrm{m}$ than the unaffected sample, accompanied by the corresponding increase of the maximum coarse sizes. In the samples of the lower, interior area of the Torre, on the other hand, the density of these fine particles is greater in the detriorated than in the unaffected samples. This is attributed to the fact that the form and cause of the deterioration is also different to that of the blocks situated in the upper, exterior areas. In this lower part there is a very high degree of humidity, a result of the absorption of subterranean water through capillarity combined with little ventilation, which in addition to breaking down the particles carries salts through the walls. These salts crystallize and change the original granulometry of the stone (1).

Figure 8 shows three graphs containing all the curves of the internal (I) and external (E) part of the same block of stone. Each of them belongs to a different area of the building, ie, the lower part, first and second level, with the same effect that has already been pointed out 

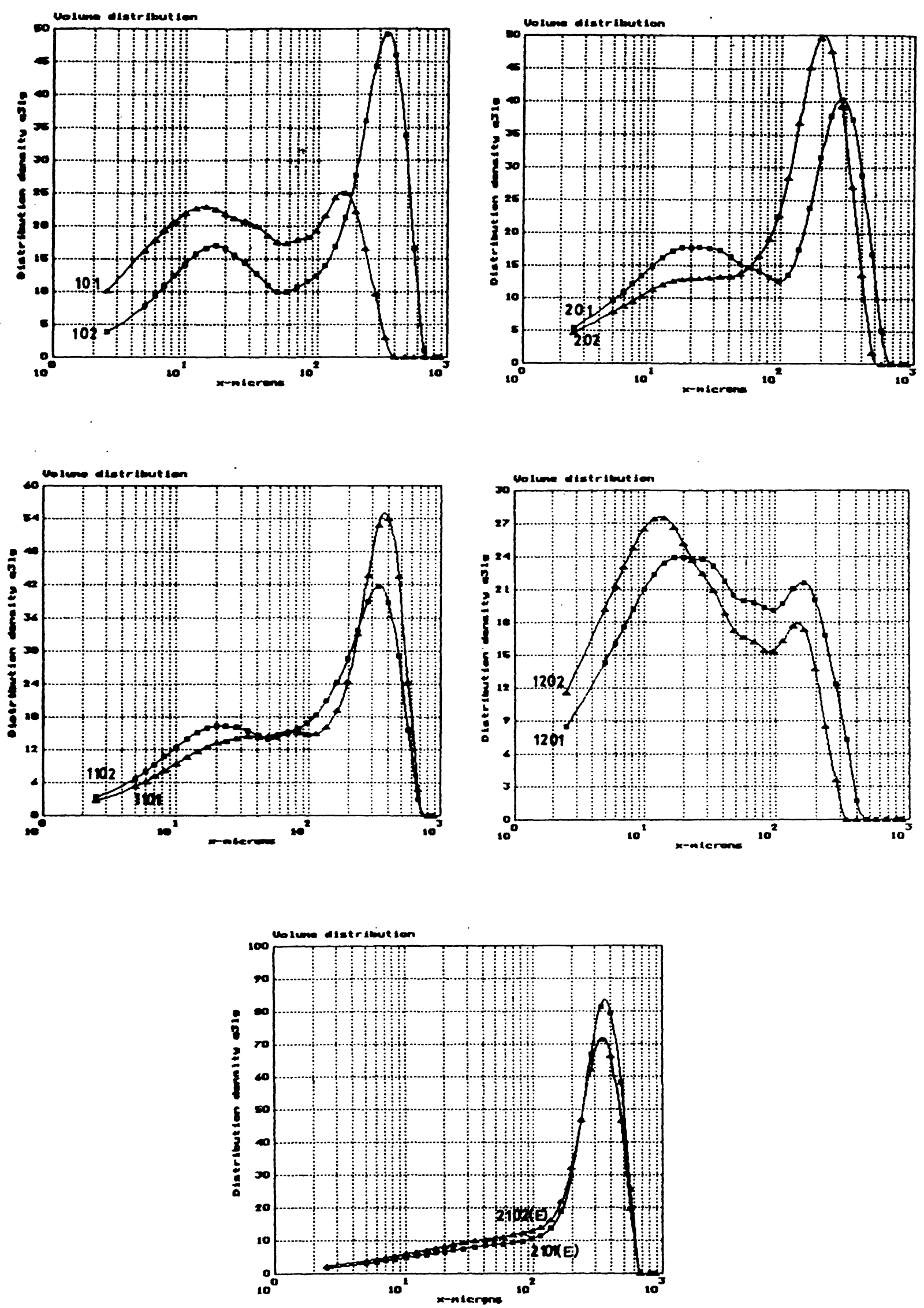

Fig. 7 - Curvas de densidad de distribución agrupadas por parejas de muestras deteriorada y no deteriorada del mismo área del edificio.

Fig. 7 - Distribution density curves grouped by deteriorated and unaffected pairs of samples from the same building area. 

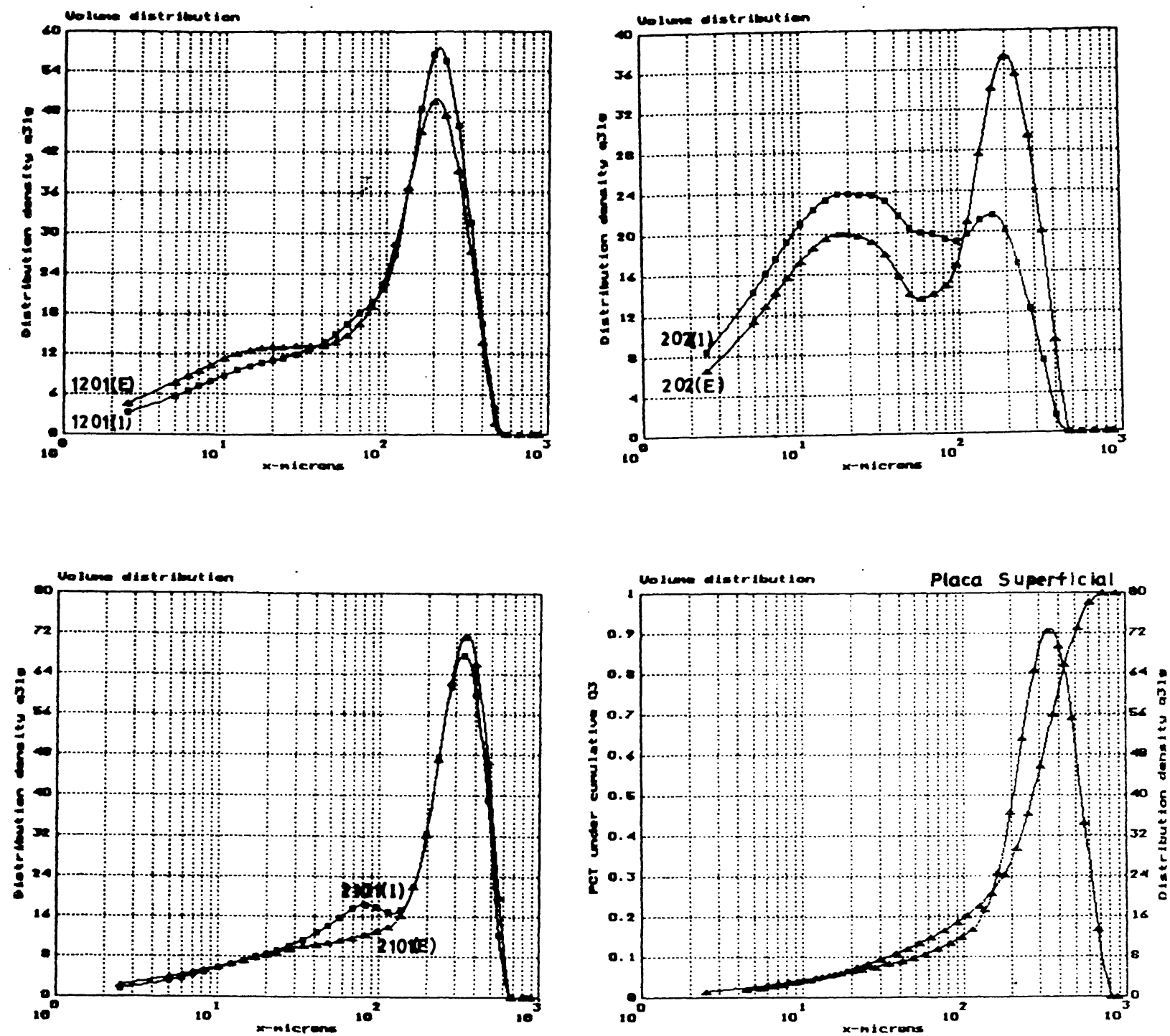

Fig. 8 - Curvas de densidad de distribución agrupadas por parte interna (I) y parte externa (E) de un mismo bloque de piedra Curva acumulativa y curva de densidad de distribución por tamaños de una muestra de placa superficial consecuencia del deterioro.

Fig. 8 - Distribution density curves grouped by the internal (I) and external (E) part of the same block of stone. Accumulative and distribution density curves of a sample from a deteriorated surface patch.

indicábamos de las muestras no deterioradas al compararlas con las deterioradas. Esto significa que hay menos partículas finas en la parte externa que en la parte interna de la misma piedra.

La figura 8 también incluye una gráfica con las dos curvas de la muestra tomada en una placa superficial consecuencia del deterioro. El volumen de partículas con tamaños menores de $100 \mu \mathrm{m}$ que han quedado después del proceso de deterioro es bastante inferior.

Los valores dados en la tabla I son los porcentajes del volumen de partículas para los tamaños de las fracciones siguientes: arcilla más limo muy fino; limo; in the unaffected samples after comparing them with the deteriorated samples. This means there are fewer fine particles in the external part than in the internal part of the same stone.

Figure 8 also includes a graph with the two curves of the sample taken from a surface layer resulting from deterioration. The volume of particles with a size below $100 \mu \mathrm{m}$ remaining after the deterioration process is rather lower.

The values given in Table I are the percentages of the particle volume for the sizes of the following fractions: clay and very fine silt; silt; very fine sand; fine sand; 
arena muy fina; arena fina; y arena media; y los porcentajes del volumen de partículas de tamaños menores de $100 \mu \mathrm{m}$ y los de tamaño mayor de $500 \mu \mathrm{m}$.

La terminología usada para la distribución de tamaños es la de Pettijohn (6).

Las partículas de tamaño limo predominan en las muestras (101) (1201) y (1202), seguidas de las de arena y arcilla. Desde el punto de vista de textura estas tres muestras son clasificadas como limo-areno-arcillosas, y las muestras restantes como areno-limo-arcillosas.

Estos valores dados en la tabla I reiteran los criterios expresados anteriormente. Las fracciones finas son ligeramente inferiores en la piedra deteriorada comparada con la no deteriorada de la misma pareja. El mismo tipo de diferencia, aún más acusada, existe entre la parte interna y la parte externa de un mismo bloque de piedra. Este hecho se aprecia mejor en las muestras de mayor finura (1201) y (1202), y es insignificante en aquéllas de textura más gruesa. Es lógico que las piedras sometidas a los agentes externos de alteración, principalmente si están situadas en las partes altas y exteriores del monumento, hayan perdido más partículas finas del material cementante en la parte más externa o superficial que en el interior, tanto en las muestras deterioradas como en las no afectadas. medium sand; and the percentages of the particle volume of sizes under $100 \mu \mathrm{m}$ and above $500 \mu \mathrm{m}$.

The terminology used for the size distribution is that of Pettijohn (6).

The silt-size particles are predominant in samples (101) (1201) and (1202), followed by those of sand and clay. From the point of view of texture these three samples are classified as silt-sand-clay and the remaining samples as sand-silt-clay.

The values given in Table I reiterate the criteria expressed above. The volume percentages of the fine fractions are slightly lower in the deteriorated stone compared with the unaffected stone of the same pair. The same kind of difference is even more noticeable between the internal and external part of the same block of stone. This fact is best observed in the samples with the greatest fineness, (1201) and (1202), and it is insignificant in those with the coarsest texture. It is logical that the stone exposed to weathering, especially that situated in the upper, exterior part of the building, should lose the fine particles, which is cementing material, in the external or surface part to a larger extent than in the interior, both in the deteriorated and in the unaffected samples.

TABLA I

DISTRIBUCION DEL TAMAÑ̃O DE PARTICULAS.

\begin{tabular}{|c|c|c|c|c|c|c|c|}
\hline Muestra & $\begin{array}{l}<4,50 \mathrm{~mm} \\
\text { Arcllk y limo } \\
\text { muy nino. (\%) }\end{array}$ & $\begin{array}{l}\text { 4,5-62,5 } \mu \mathrm{m} \\
\text { Limo. (\%) }\end{array}$ & $\begin{array}{c}62,5-125 \mu \mathrm{m} \\
\text { Arena muy fnn. } \\
\text { (\%) }\end{array}$ & $\begin{array}{c}125-250 \mu \mathrm{m} \\
\text { Arena Ana. (\%) }\end{array}$ & $\begin{array}{c}250-500 \mu \mathrm{m} \\
\text { Arena medka. (\%) }\end{array}$ & $>500 \mu \mathrm{m}(\%)$ & $<100 \mu \mathrm{m}(\%)$ \\
\hline 101-I & 16,14 & 52,58 & 13,29 & 15,71 & 2,28 & - & 78,21 \\
\hline 102-I & 6,22 & 33,85 & 8,37 & 17,97 & 30,48 & 3,11 & 46,52 \\
\hline 201-I & 8,66 & 39,91 & 9,24 & 19,53 & 21,66 & 1,00 & 55,45 \\
\hline 201-E & 5,89 & 34,46 & 10,89 & 21,45 & 26,81 & 0,50 & 48,63 \\
\hline 202-I & 7,43 & 31,29 & 14,90 & 31,79 & 14,59 & - & 48,67 \\
\hline 202-E & 5,21 & 27,62 & 14,85 & 34,94 & 17,38 & - & 43,04 \\
\hline $1101-I$ & 4,34 & 29,64 & 10,38 & 16,41 & 34,06 & 5,17 & 41,78 \\
\hline $1102-1$ & 5,41 & 32,26 & 13,85 & 13,32 & 31,88 & 3,28 & 48,32 \\
\hline $1201-\mathrm{I}$ & 13,52 & 55,00 & 13,53 & 14,18 & 3,77 & - & 78,58 \\
\hline 1201-E & 10,53 & 43,64 & 11,45 & 23,90 & 10,48 & - & 61,96 \\
\hline $1202-\mathrm{I}$ & 18,54 & 59,63 & 10,95 & 10,24 & 0,64 & - & 86,28 \\
\hline $1201-\mathrm{I}$ & 2,63 & 21,85 & 12,22 & 20,94 & 40,16 & 2,20 & 33,77 \\
\hline 2101-E & 3,67 & 20,04 & 8,79 & 20,66 & 43,33 & 3,51 & 30,09 \\
\hline 2102-E & 2,76 & 16,22 & 7,10 & 19,15 & 50,25 & 4,52 & 24,08 \\
\hline
\end{tabular}


Observando los valores granulométricos de las piedras que han sufrido deterioro se deduce que no son comparables unos con otros, ni tampoco son comparables los de las piedras no deterioradas. Esto significa que las primeras no forman un grupo granulométrico específico ni tampoco lo forman las segundas, que sería el caso si existiera una relación directa entre textura y grado de deterioro. Muestras con un contenido muy alto de partículas finas muestran deterioro -es el caso de la (1201)-, mientras que otras con porcentajes muy inferiores de estas partículas no lo muestran, como por ejemplo la (1102).

Las areniscas con textura más gruesa son las del nivel $2^{\circ}$ de la fachada oeste de la Catedral Nueva, tanto la deteriorada (2101) como la no deteriorada (2102). Aquéllas con textura más fina son; la muestra deteriorada del interior de la entrada a la torre (101), y las muestras deteriorada y no deteriorada del nivel $1^{\circ}$ de la fachada norte de la Catedral Vieja (1201) y (1202). Estos datos confirman de nuevo que la mayor o menor finura de estas piedras no tiene relación con el grado de deterioro, siempre que la textura de la arenisca sea la requerida para su uso como material de construcción, como se verá en este estudio.

El deterioro selectivo, según creemos, es consecuencia de la forma en la que cada bloque de piedra fue cortado en relación al sedimento y del modo que era entonces colocado en el paramento del edificio, es decir, de la posición que adquiera la superficie externa de la piedra respecto a su anisotropía estructural (trabajo en prensa).

En general, repetimos, todas las muestras son muy similares granulométricamente, y más aún las piedras situadas en la misma zona del monumento. Esto coincide con los resultados de otro estudio, citado anteriormente, respecto a las características físico químicas y físico mécanicas de las mismas muestras.

La tabla II contiene otros valores, tales como los de las medianas, que varían de unas muestras a otras entre $16,50 \mu \mathrm{m}$ a $217,11 \mu \mathrm{m}$, o el tamaño mayor de los granos de arena, que no superan las $675 \mu \mathrm{m}$. Estos datos son acordes con todo lo ya expuesto.

Cuando se comparan los resultados granulométricos de las piedras del monumento con los de las piedras extraídas en la actualidad de la cantera de Villamayor, es significativa la semejanza de las primeras, piedras históricas, con aquéllas de cantera clasificadas como tipo $\mathrm{F}$ e idóneas para ser empleadas como material de construcción. Esto permite deducir las condiciones granulométricas de una arenisca con calidad óptima,
After studying the granulometric values of the deteriorated stones, it is found that they are not comparable with each other, neither are those of the unaffected stones. This means that the former do not form one specific granulometric group nor do the latter form another, which would be the case if there were a direct relationship between the texture and the degree of deterioration. The samples with a very high content of fine particles show deterioration as is the case with (1201), while others with a very much lower percentage of these particles do not, as for example sample (1102).

The sandstones with the coarsest texture of the samples studied are those from the second level of the western façade of the Catedral Nueva, both the deteriorated (2101) and the unaffected (2102) sample. Those with the finest texture are the deteriorated sample from the interior of the entrance to the tower (101) and the deteriorated and unaffected samples from the first level of the northern façade of the Catedral Vieja (1201) and (1202). These data confirm again that the greater or lesser fineness of these stones has no connection with the degree of deterioration, as long as the texture of the sandstone is that required for its use as a building material, as will be seen later in this study.

\section{Selective deterioration is thus believed to be the $\mathbf{C}$} consequence of the form in which each block of stone was cut in relation to the sediment and the way it was then placed in the wall of the building, ie, the position of the external surface of the stone as regards its structural anisotropy (the study is in the printing stage).

In general, we repeat, all the samples are very similar granumetrically, even more so when the stones are situated in the same area of the building. This coincides with the contents of another study, mentioned earlier, regarding their physico-chemical and physicomechanical characteristics.

Table II contains other values, such as the mediums, which vary from $16.50 \mu \mathrm{m}$ to $217.11 \mu \mathrm{m}$ between samples, or the largest size of the sand grains, which do not go beyond $675 \mu \mathrm{m}$. These datum agree with the above.

When comparing the granulometric results of the stones in the building with those of the stones extracted today from the quarry of Villamayor, the similarity of the former, the historical stones, with the quarry stones classified as type $F$ and as ideal for building purposes is significant. The granulometric conditions of topquality sandstone may thus be established, confirmed by its century-old resistance to weathering in the 
TABLA II

\begin{tabular}{|c|c|c|c|c|c|c|}
\hline Muestra & $\begin{array}{l}10 \% \\
\text { del volumen de } \\
\text { particulas tienen } \\
\varnothing \text { nenor que,pm }\end{array}$ & $\begin{array}{c}25 \% \\
\text { del volumen de } \\
\text { particulas tlenen } \\
\varnothing \text { menor que } . \mu \mathrm{m}\end{array}$ & $\begin{array}{c}50 \% \\
\text { del wolumen de } \\
\text { particulas tienen } \\
\varnothing \text { menor que. } \mu \mathrm{m}\end{array}$ & $\begin{array}{c}75 \% \\
\text { del wolumen de } \\
\text { particulas tlenen } \\
\varnothing \text { menor que. } \mu \mathrm{m}\end{array}$ & $\begin{array}{c}90 \% \\
\text { det volumen de } \\
\text { particulas tienen } \\
\varnothing \text { menor que } \mu \mathrm{m}\end{array}$ & $\begin{array}{c}\text { Tamaño } \\
\text { mayor de } \\
\text { particulas } \mu \mathrm{mm}\end{array}$ \\
\hline 101-I & 2,98 & 7,50 & 23,44 & 90,00 & 173,63 & 365 \\
\hline $102-I$ & 6,92 & 18,50 & 137,69 & 305,00 & 424,70 & 615 \\
\hline 201-I & 5,20 & 15,50 & 69,46 & 255,00 & 354,05 & 615 \\
\hline 201-E & 7,66 & 25,00 & 115,49 & 255,00 & 366,98 & 615 \\
\hline 202-1 & 6,20 & 21,50 & 110,38 & 215,00 & 287,67 & 515 \\
\hline 202-E & 9,15 & 37,50 & 133,72 & 215,00 & 300,04 & 515 \\
\hline $1101-I$ & 10,13 & 35,00 & 173,23 & 350,00 & 462,24 & 675 \\
\hline $1102-1$ & 7,93 & 22,00 & 115,51 & 280,00 & 416,35 & 675 \\
\hline $1201-1$ & 3,46 & 9,00 & 26,67 & 90,00 & 182,15 & 365 \\
\hline 1201-E & 4,30 & 12,00 & 46,14 & 175,00 & 259,52 & 435 \\
\hline $1202-I$ & 2,66 & 6,50 & 16,50 & 52,50 & 131,83 & 305 \\
\hline $1201-I$ & 18,01 & 63,00 & 217,11 & 340,00 & 426,86 & 515 \\
\hline 1101-E & 14,67 & 75,00 & 239,17 & 350,00 & 448,78 & 565 \\
\hline 2102-E & 20,59 & 125,00 & 275,01 & 380,00 & 470,39 & 615 \\
\hline
\end{tabular}

confirmadas por las que permanecen desde hace muchos siglos en el monumento. Estas condiciones suponen un porcentaje en el volumen de partículas finas (tamaño inferior a $100 \mu \mathrm{m}$ ) superior a 30 , aparte de otras características relacionadas íntimamente con éstas y descritas en estudios antes mencionados. Areniscas con otros valores inferiores a los referidos pertenecen a otros tipos, que no tienen las propiedades tecnológicas necesarias para utilizar como materiales de construcción.

La opinión de otros autores (7) es que la granulometría óptima se encuentra en areniscas seleccionadas con un tamaño de grano entre 0,250 y $0,125 \mathrm{~mm}$, conteniendo al menos el $10 \%$ de partículas con un tamaño más pequeño que $0,06 \mathrm{~mm}$, y sin fragmentos gruesos (mayores de $22 \mathrm{~mm}$ ). Para otros (8) las areniscas, consideradas como Tipo A de calidad buena, tienen entre otras características un tamaño de grano medio del orden de $1,1 \mathrm{~mm}$.

\section{CONCLUSIONES}

- Desde un punto de vista granulométrico, las areniscas de Villamayor, sin contenido de carbonatos, son óptimas como material de construcción cuando el volumen de partículas de tamaño inferior a $100 \mu \mathrm{m}$ es superior al $30 \%$. building. These conditions include a volume percentage of fine particles (with a size below $100 \mu \mathrm{m}$ ) above 30, apart from other characteristics closely related to them and described in the studies mentioned earlier. Sandstones with lower values to those in this study belong to other types that do not have the technological properties necessary for using as building material.

According to some authors (7), the best granulometry is found in selected sandstones with a grain size of between 0.250 and $0.125 \mathrm{~mm}$, containing at least $10 \%$ of particles of a size smaller than $0.06 \mathrm{~mm}$, and without large fragments (of more than $22 \mathrm{~mm}$ ). Others (8) consider that sandstones, such as Type A, are exceptional with a medium grain size of $1.1 \mathrm{~mm}$, among other characteristics.

\section{CONCLUSIONS}

- From a granulometric viewpoint, Villamayor sandstones without carbonates are the best building material when the particle volume of a size below $100 \mu \mathrm{m}$ lies above 30\% 
- No se ha encontrado una relación directa entre el deterioro superficial observado en algunas de las piedras de las Catedrales y su mayor o menor finura textural.

- La constitución física de todas las areniscas tomadas de las Catedrales es semejante, y es semejante también a la que tienen las piedras extraĺdas en la actualidad de la cantera de Villamayor clasificadas como tipo F.

\section{AGRADECIMIENTO}

Los autores desean expresar su agradecimiento a D. José Manuel Llueca del ICCET/CSIC por su valiosa colaboración.
- It is found that there is no connection between the surface deterioration observed in some of the stones of the cathedrals and their more or less textural fineness.

- The sandstones of the samples from the cathedrals are physically similar and are also similar to the stones that are extracted today from the Villamayor quarry classified as type $F$.

\section{ACKNOWLEDGEMENT}

The authors wish to thank Mr José Manuel Llueca of the ICCET/CSIC for his valuable collaboration.

\section{BIBLIOGRAFÍA}

(1) MARTIN PATINO, M.T., MADRUGA, F., SAAVEDRA, J. (1992). Characterization of the sanstone of the Salamanca Cathedrals. Proceeding 7th. International Congress on Deterioration and Conservation of Stone. Lisboa (Portugal), pp. 315-324.

(2) MARTIN PATINO, M.T., MADRUGA, F., SAAVEDRA, J. (1993). The internal structure of the Villamayor Sandstone as it affects its use as a construction material. Applied Clay Science, 8, pp. 61-77.

(3) SAAVEDRA, J., MADRUGA, F., MARTIN PATINO, M.T. (1993). Clasificación de la arenisca de Villamayor (Salamanca) por sus características tecnológicas y estructura interna. Bol. Geol. Minero . Vol. 104-6, 665-663.

(4) FRIAS, M., LUXAN, P., SANCHEZ DE ROJAS, M.I. (1988). Espectrometría de difracción por rayos laser. Materiales de la Construcción, Vol. 38, $\mathrm{n}^{\circ} 212$, pp. 37-52.

(5) VISHER, G.S. (1969). Grain size distribution and depositional process. J. Sediment. Petrol. 39, pp. 1077-1106.

(6) PETTIJOHN, F.J., POTTER, P., SIEVER, R. (1972). Sand and Sandstone, Springer-Verlag, pp.70-71.

(7) ARRIBAS, A., POLO, V., JIMENEZ, E. (1984). La enfermedad de la piedra en la arenisca de Villamayor. En estudio sobre las alteraciones y tratamiento de la piedra de Villamayor. Ed. Caja de Ahorros y M.P. de Salamanca. pp. 5-169.

(8) ORDAZ, J., ESBERT, R., MONTOTO, M., DE CASO, F., ALONSO, F.J. (1984). Estado de alteración y alteración futura de la piedra de Villamayor de los monumentos salmantinos; interpretación petrográfica. En estudio sobre las alteraciones y tratamientos de la piedra de Villamayor. Ed. Caja de Ahorros y M. P. de Salamanca. pp. 315-419. 